\title{
CONSIDERAÇÕES SOBRE O AMOR PELO BANAL, A LITERATURA E AS OUTRAS ARTES EM ANTÓNIO LOBO ANTUNES
}

Glaura Cardoso Vale

\begin{abstract}
RESUMO: Na obra de António Lobo Antunes, encontramos, dentre suas referências à literatura e às outras artes, uma forte menção aos suvenires que compõem a casa portuguesa. Este ensaio discorre sobre a implicação desses pequenos objetos numa escrita que convoca a literatura, a música, o cinema e a pintura para auxiliar o narrar.
\end{abstract}

Palavras-chaves: António Lobo Antunes; Literatura Portuguesa; crônica.

\section{CONSIDERING THE LOVE OF THE ORDINARY, LITERATURE AND OTHER ARTS IN ANTÓNIO LOBO ANTUNES}

ABSTRACT: In the work of António Lobo Antunes, among references to literature and other arts, it is found a strong mention of the souvenirs that make up a Portuguese house. This essay discusses the involvement of these small objects in his writing, which summons literature, music, cinema and painting to account for the narrating act.

Keywords: António Lobo Antunes; Portuguese Literature; chronic.

Sabidamente, a obra de António Lobo Antunes implica uma relação com suas referências literárias e o seu constante referendar às outras artes, convocando-as muitas vezes para dar conta do narrar, sobretudo nos romances iniciais que têm a Guerra Colonial e o hospital psiquiátrico como tema. A solicitação dessas referências confirma uma reversibilidade entre leitura e escrita não sendo, portanto, processos distintos e independentes na construção da obra do autor. Neste artigo, procura-se perceber alguns aspectos relacionados também a elementos menores, inconsistentes, frágeis, descartáveis, que correspondem ao banal, termo aplicado pelo próprio autor, e que perpassam as crônicas e romances. Este texto privilegiará parte de suas crônicas em diálogo com os romances da fase inicial, por se relacionarem mais fortemente com a memória do autor, embora sua escrita dita autobiográfica seja marcada pela ficcionalização de suas lembranças.

Alguns anos após o retorno de Lobo Antunes da guerra colonial em Angola, onde serviu como médico combatente pelo exército português de 1971 a 1973, publica Memória de elefante (1979), Os cus de Judas (1979) e Conhecimento do inferno (1980), livros que compõem a

\footnotetext{
1 Doutora em Estudos Literários FALE/ UFMG. Residente pós-doutoral com bolsa de PNPD/CAPES, junto ao Programa de Pós-graduação em Comunicação da UFMG.
} 


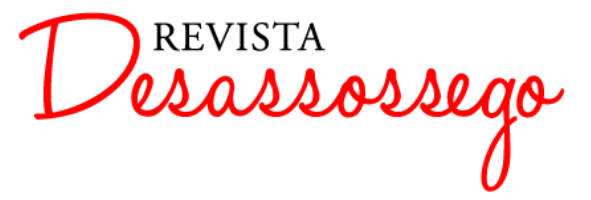

DESASSOSSEGO 13 | JUN/2015 | ISSN 2175-3180

DOI: http://dx.doi.org/10.11606/issn.2175-3180.v7i13p38-54

trilogia da agonia ou da aprendizagem. O contexto da guerra em seu segundo romance representa uma ruptura, um momento da perda das grandes ilusões, da perda do conforto da casa portuguesa e de certos valores herdados. Nesse romance, a memória passa a ser mediada por essa experiência, e suas referências catalisam imageticamente personagens, espaços, sensações. O banal aqui se refere tanto aos objetos que compõem a casa, quanto às situações corriqueiras, cenas de jantares ou viagens de férias que revelam a ternura na infância.

Não compete a este artigo promover o esgotamento do tema em toda a obra, dada sua extensão, ao mesmo tempo observa-se que tanto as referências à literatura e às outras artes, quanto o banal, reincidirão em seus demais romances, ora como estrutura buscada na música, conforme se verá mais adiante, ora para mostrar homens e mulheres à margem e marginalizados, solitários, vazios de experiência transmissível e esvaziados de afeto. Apostando na transversalidade ao convocar gêneros distintos (crônica e romance), propõese mostrar como esse mundo em diminuto coexiste com as referências canônicas - mundo pertencente não apenas ao imaginário do autor e seus personagens, mas em certa medida tributário do imaginário de escritores como Proust, Balzac, Dostoiévski, Tolstói, tão caros a Lobo Antunes. A hipótese é de que o "banal” em Lobo Antunes parte também de suas leituras e das outras artes solicitadas, verificável também em suas entrevistas.

Observa-se, nas crônicas, ${ }^{2}$ o trabalho contínuo de observação e filtragem da memória do leitor Lobo Antunes incidindo na sua escrita. Aqui, o ato da leitura está explicitamente revelado, podendo até apresentar uma irônica receita prescrevendo como o leitor deve lê-lo, fazer alusão a Joyce, como em "Retrato do artista quando o jovem - II", ou, no caso do cinema, a Fellini $81 \frac{12,3}{3}$ em "António 56 1/2". Acredita-se que a escrita loboantuniana, desde os romances iniciais, ao convocar o cânone literário e as demais referências culturais (como a música, a pintura, o cinema, a publicidade; também os ícones das revoluções, os desbravadores e navegadores portugueses, os ditadores, os monumentos etc.), misturados ao banal (bibelôs portugueses, naperons, que compõem a casa), quer promover um diálogo incessante entre aquilo que é dado e o efeito multiplicador desse

\footnotetext{
${ }^{2}$ Em relação às crônicas, Maria Alzira Seixo propõe quatro divisões: as autobiográficas, as ficcionais, as que evocam figuras míticas da geração do autor ou de sua família, as de matéria literária, que apresentam um procedimento de leitura e escrita, aqui entendidas como a exposição de uma biografia literária.

3 A estrutura deste filme se dá como uma mise en abyme, Marcelo Mastroianni faz o personagem de um diretor de cinema a refletir sobre o filme a ser feito.
} 
“saber" no texto. Por vezes, possibilitando mesmo a aproximação de outros saberes, outras vezes, numa livre associação, contrastando o erudito e o popular, se referindo ao jazz, fenômeno americano, como modelo de frasear, por exemplo.

$\mathrm{Na}$ crônica "O começo do mundo", do Quarto livro de crônicas, António Lobo Antunes inicia assim: "Durante muito tempo julguei que o mundo começava no sítio onde morei desde que nasci. Naquela casa, naquele jardim, naqueles cheiros. Na mesa de pedra sob o caramanchão" (2011, p. 253). Pensava que o mundo era restrito à sua família, ao poço e à fogueira. Como também à lua na acácia, à cozinha enorme que vira encolher, aos cegos que cantavam na rua, à padaria cheia de labaredas e fantasmas, ao doido que vendia passarinhos, ao policial pequeno e gordo que se punha a lhe sorrir. E como não dizer, então, do amor pelo banal e a relação desse amor com as suas referências à literatura e às outras artes? Alcatifas, naperons, bibelôs, relógios de pêndulo ou de cuco são artefatos da casa portuguesa que, junto a bibes e triciclos, rondam o imaginário loboantuniano, sendo imagens recorrentes que também auxiliam a composição da cena da leitura e da escrita em sua obra:

Nasci e cresci num acanhado universo de croché, croché da tia-avó e croché manuelino, filigranaram-me a cabeça na infância, habituaram-me à pequenez do bibelot, proibiram-me o canto nono de Os Lusiadas e ensinaram-me desde sempre a acenar com um lenço em lugar de partir (ANTUNES, 2003, p. 37).

Nesse trecho, o narrador de Os cus de Judas queixa-se sobre a perda desse universo, do mundo em diminutivo, de pesos de papéis que nevam dentro, teia de hábitos tristes, mundo que se evaporava, quando de repente se vê, diferentemente do mergulho em almofadas bordadas, numa camionete desconfortável, cheia de tropas, circulando numa paisagem inimaginável, onde tudo flutua: "as cores, as árvores, os gigantescos contornos das coisas, o céu abrindo e fechando escadarias de nuvens em que a vista tropeça até cair de costas, como um grande pássaro extasiado” (ANTUNES, 2003, p. 38).

Em entrevista a Luís Almeida Martins à revista Visão, diz: "há em meus livros um fascínio muito grande pelas casas das porteiras, pelos naperons, pelos bibelots em cima da televisão, pelo horror ao vácuo que leva aquelas pessoas a preencherem todas as superfícies planas. Adoro isso" (ANTUNES; In: ARNAUT, 2008, p. 256). Interessante que nesse 
momento o autor distingue esta característica, de acumular objetos, da casa dos pais, que, segundo ele, era austera, com muitas prateleiras de livros e quase sem móveis. Importa aqui destacar a sua relação com o banal, independentemente de uma implicação direta com a casa onde nascera, pensando a construção dessa memória a partir do que observa e lê, da memória alheia, a memória que partilha com os livros. Como pode ser observado no prosseguimento da entrevista, quando solicita Thomas Mann, que dizia "o que faz de mim um artista é o amor pelo banal", e Balzac "se uma pessoa quer ser romancista, tem de remexer em toda a vida social, porque o romance é a história privada das nações” (In: ARNAUT, 2008, p. 256).

Em "De Deus como apreciador de jazz", do Segundo livro de crónicas, por exemplo, Lobo Antunes apresenta certo procedimento de escrita pautado nas próprias preferências, como um "manual” de instruções:

Beethoven, Brahms e Mahler serviram-me de modelo para A Ordem Natural das Coisas, A Morte de Carlos Gardel e O Manual dos Inquisidores, até me achar capaz de compor por conta própria juntando o que aprendi com os saxofonistas de jazz, principalmente Charlie Parker, Lester Young e Ben Webster (...) (2007, p. 138).

Nesse excerto, entende-se que a música serve para o autor como modelo, sendo possível perceber essa referência na sua ficção, principalmente no frasear do jazz de que tanto fala: "A gente aprende a frasear com eles. Charlie Parker. John Lester. Johnny Rodgers. Thelonious Monk", diz Lobo Antunes ao jornal Público. Na referida crônica é curioso observar que o escritor ressalta as influências da música erudita em algumas de suas obras, até o momento em que compõe por conta própria, mas não abandona os jazzistas. ${ }^{4}$ Isso indica uma possível relação de intimidade e apreciação do autor com um tipo específico de composição criada pelos negros americanos, que, grosso modo, traz em si a mistura de certos traços musicais da África Ocidental com a nova cultura, a Norte Americana (HESS, 1997). A crônica que inicia com um retrato de Charlie Parker preso à parede, o qual o autor crescera contemplando, termina por falar de Deus e do possível gosto deste pelo jazz: O jazz é referência forte em Os cus de Judas, tendo em vista tanto o ponto de vista histórico música dos negros trazidos da África -, quanto a música em si, que induz a certa

\footnotetext{
${ }^{4}$ Em Os cus de Judas, figuras como John Coltrane, Charlie Parker, Ben Webster e Louis Armstrong se misturam no discurso a outras personalidades, sejam das outras artes ou da política. Tais personalidades não só funcionam como significantes no texto, mas também promovem uma marcação rítmica em toda a narrativa, seja pela multiplicidade, pela função mediadora ou pelo deslocamento.
} 
embriaguez no frasear e silenciar, contestação e sopro ao mesmo tempo. No romance, o jazz é constantemente evocado, seja na comparação dos negros acocorados a observar os recém-chegados em Luanda com o saxofone soprado por John Coltrane (2003, p. 24), seja pela observação do povo, "cuja inesgotável vitalidade" o narrador já entrevira "no trompete solar de Louis Armstrong” (2003, p. 57).

Do mundo particular e diminuto (o cartaz de Parker) para o mundo global ou o inverso, é o escritor a compor uma biografia literária, sua inserção na tradição ao passo que também a inventa, num efeito espiralar, uma vez que retoma esse imaginário ora citando esse repertório, ora buscando na música uma estrutura para seus romances. Repetir com diferença, nutrindo-se do que lê e observa, talvez a figura do catalisador seja pertinente para pensar esse arranjo textual. Sendo assim, não há dúvida quando Lobo Antunes diz que todo livro é na verdade a biografia do autor. Ele mantém seus eleitos e se mantém no diálogo com seu próprio tempo. Ou como diz Piglia, ao se referir à própria tradição: “os escritores atuais buscam construir uma memória pessoal que sirva, ao mesmo tempo, como ponte para a tradição perdida" ${ }^{5}$ (1991, p. 66; tradução minha). Uma literatura que, segundo ele, tem a forma de um complô: "em segredo, os conspiradores buscam os rastros da história esquecida. Buscam recordar a ex-tradição, o que passou e os rastros deixados" (PIGLIA, 1991, p. 66; tradução minha). A tradição da qual Lobo Antunes se vale será aquela que o ajudará a renovar a arte do romance, embora não se tenha como escapar do drama pessoal, das grandes tragédias que correm em paralelo, dos fantasmas imperiais e da vida comezinha: vidas solitárias marcadas pela incomunicabilidade. ${ }^{7} \mathrm{O}$ que tomo como o "banal", definição utilizada pelo próprio Lobo Antunes, Denis Leandro Francisco, em sua tese de doutorado, tomará por kitsch, observando aspectos negativos e positivos desses objetos:

Em Lobo Antunes, a casa atual mostra-se, com freqüência, esvaziada e desinteressante e os sujeitos ficcionais passam a habitar,

\footnotetext{
5 "Los escritores actuales buscamos construir una memoria personal que sirva, al mismo tiempo, como puente con la tradición perdida" (PIGLIA, 1991, p. 66)

6 "En secreto, los conspiradores buscan los rastros de la historia olvidada. Buscan recordar la ex-tradición lo que ha pasado y ha dejado su huella" (PIGLIA, 1991, p. 66).

${ }^{7}$ Como em $O$ esplendor de Portugal (1997), a ausência de amor, a morte, o dilaceramento do corpo e da alma, a incomunicabilidade entre sujeitos que estão à deriva, postos à margem da sociedade. Paralelamente ao relato dos filhos Carlos, Rui e Clarisse, que voltaram a Lisboa na condição de retornados, neste romance, temos o relato da mãe, Isilda, lançada à própria sorte, numa saga que a levará a atravessar o território angolano lutando desesperada contra a guerra até à morte.
} 
imaginariamente, o espaço atraente e colorido, recheado de ornatos e de enfeites, da casa passada, evidenciando a inegável permanência residual desses espaços de interioridade. Bachelard concorda que "as diversas moradas de nossa vida se interpenetram", mas, enquanto para ele essa contaminação é sempre harmônica e os elementos contaminantes são sempre descritos como relíquias, "tesouros dos dias antigos", na ficção antuniana essa contaminação pode tanto operar (...) a partir de elementos de significação destrutiva (como a doença que corrói o corpo e a casa de Soraia) como de elementos afirmativos (2011, p. 114).

O que Francisco chama de "casa atual", podemos entender como a casa no retorno da guerra, a outra casa pertence ao passado, sendo sempre uma lembrança fugidia, onde a ternura reside, com fantasmas que fazem ranger o assoalho, e os mortos a desaparecerem nos retratos fixados às paredes ou esquecidos num sótão. Ao mesmo tempo em que povoar de objetos a casa é uma forma de preencher vazios, o seu esvaziamento (a não presença desses objetos) constata uma perda. Por isso, não fica difícil perceber, no momento em que o narrador de Os cus de Judas, ao entrar no apartamento, acentua (para a mulher que o acompanha) o andar desnudo, que a ausência de pequenos achados e suvenires indica a solidão e afastamento desse lugar idealizado, a casa agora desfeita pela separação, bem como a perda da inocência, no retorno da guerra. Tais objetos, rearranjados pela memória, possível zona de conforto frente à vida atormentada dos seus personagens, dão ao leitor pistas não apenas dos cenários íntimos, onde se encontram Flash Gordon e Mandrake, ou mesmo Charlie Parker, mas também da rua, dos cafés, dos restaurantes, das casas noturnas, dos bares, através dos "seus candeeiros Arte Nova de gosto duvidoso", cujos frequentadores de cabeças juntas segredam "banalidades deliciosas na euforia suave do álcool" (ANTUNES, 2003, p. 32). Nesses recintos, onde o narrador confidencia o desastroso jogo de matar, salvar e morrer, pairam os encontros casuais e a superficial troca de afetos regidos pela música de fundo que confere aos sorrisos de quem os ocupa "a misteriosa profundidade dos sentimentos que não possuímos nunca" (ANTUNES, 2003, p. 32). "Profundidade" também garantida pelo balde de "espumante Raposeira" à espera, nos cabarés, do dia de seguir para a zona de combate. O cumprimento, enfim, da profecia da família em se "tornar homem", cuja avidez triste e cínica, "feita de desesperança cúpida", e a pressa de se esconder de si próprio, o fizeram substituir para sempre "o frágil prazer da alegria infantil, do riso sem reservas nem subentendidos, embalsamado de pureza" (ANTUNES, 2003, p. 33); riso que parece escutar de tempos em tempos à noite, ao voltar 
para a casa numa rua deserta, ecoando nas suas costas "numa cascata de troça". Dois mundos em contraste. De um lado, os mimos e prendas que marcam a infância; do outro, a decoração excessiva das casas noturnas, sem rastro de individualidade, marcando a vida adulta.

Essa reflexão acompanha a ideia de perda da ilusão, da crença nos "grandes lances", nos "terramotos anteriores", o que não passa, segundo o narrador de Os cus de Judas:

de uma mistificação óptica, de um engenhoso jogo de espelhos, de uma mera maquinação de teatro sem mais realidade que a cartolina e o celofane do cenário que a enformam e a força da nossa ilusão a conferirlhe uma aparência em movimento (ANTUNES, 2003, p. 32).

Nesse texto, construído sob diversas perspectivas, da infância que exibe a ternura, da guerra que exibe o horror, da situação narrativa que exibe a oscilação tempo/espaço e da incerteza de "conquista", filtradas pelo ponto de vista de um narrador já maduro, a única certeza possível é a da impotência diante da morte. Não há também possibilidade de afeto ou mesmo de diálogo em ambientes cuja doçura e inocência se encontram arruinadas, ao menos nessa voz oscilante, entre as lembranças que lhe são mais caras, a experiência traumática e o presente enunciativo. O que interessa aqui é como tais objetos que compõem a casa podem ser tomados também como referência cultural, em que o espelho, por exemplo, se faz síntese:

No vestíbulo havia um espelho biselado que de noite se esvaziava de imagens e se tornava tão fundo como os olhos de um bebé que dorme, capaz de conter em si todas as árvores do Jardim e os orangotangos dependurados das suas argolas à laia de enormes aranhas congeladas (ANTUNES, 2003, p. 12).

Não faltariam referências à pintura de representação do espelho, sobretudo relacionadas a pintores caros a Lobo Antunes, como Velázquez, que mereceu estudo de Foucault sobre o quadro Las meninas, destacando a intrincada cena produzida pelo jogo de olhares, a implicação do seu autor na tela, bem como o espelho indicando a presença do casal Real no extracampo. O espelho, no trecho acima, é também uma possibilidade de ampliação desse mundo da casa, emoldurando paisagens reais e imaginárias, para além da sua função de refletir o real imediato. $\mathrm{O}$ autor evidencia, algumas páginas à frente, sua verdadeira preocupação, o projeto de escrita:

Nunca lhe aconteceu isto, sentir que está perto, que vai lograr num segundo a aspiração adiada e eternamente perseguida anos a fio, o projecto que é ao mesmo tempo o seu desespero e a sua esperança, 
estender a mão para agarrá-lo numa alegria incontrolável e tombar, de súbito, de costas, de dedos cerrados sobre o nada, à medida que a aspiração ou o projecto se afastam tranquilamente de si no trote miúdo da indiferença, sem a fitarem sequer? (ANTUNES, 2003, p. 26).

Ironia ou não, foi justamente a guerra, experiência que minou o curso natural da vida, somada à experiência no hospital Miguel Bombarda, que deu ao autor o aporte necessário para a concretização do seu projeto. A sua tentativa de escrita anterior fora substituída pela imersão nesse outro aprendizado. Se pudesse ser destacado um outro trecho síntese, que representasse essa passagem do conforto de uma vida burguesa para o confronto com a escrita, talvez fosse este o momento, em que diz à mulher-ouvinte:

Outro vodka? É verdade que não acabei o meu mas neste passo da minha narrativa perturbo-me invariavelmente, que quer, foi há seis anos e perturbo-me ainda: descíamos do Luso para as Terras do Fim do Mundo, em coluna, por picadas de areia, Lucusse, Luanguinga, as companhias independentes que protegiam a construção da estrada, o deserto uniforme e feio do Leste, quimbos cercados de arame farpado em torno dos pré-fabricados dos quartéis, o silêncio de cemitério dos refeitórios, casernas de zinco a apodrecer devagar, descíamos para as Terras do Fim do Mundo, a dois mil quilómetros de Luanda, Janeiro acabava, chovia, e íamos morrer, íamos morrer e chovia, chovia, sentado na cabina da camioneta, ao lado do condutor, de boné nos olhos, o vibrar de um cigarro infinito na mão, iniciei a dolorosa aprendizagem da agonia (ANTUNES, 2003, p. 42-43).

Junto à dolorosa aprendizagem da agonia, não há uma tentativa de apagamento dos vestígios daquilo que lê e observa, o que parece querer apagar são as imagens da guerra e do hospital, imagens paradoxalmente fixadas na escrita muitas vezes com o auxílio de suas referências culturais, o que também ocorre quando relembra as relações desfeitas, a separação da primeira esposa, como nesta passagem de Memória de elefante numa longa reflexão sobre si e sobre a escrita, depois de constatar essa perda irreparável:

E porque é que só sei gostar, perguntou-se examinando as bolhas de gás pegadas à parede de vidro, porque é que só sei dizer que gosto através dos rodriguinhos de perífrases e metáforas e imagens, da preocupação de alindar, de pôr franjas de crochet nos sentimentos, de verter a exaltação e a angústia na cadência pindérica do fado menor, alma a gingar, piegas, à Correia de Oliveira de samarra, se tudo isto é limpo, claro, directo, sem precisão de bonitezas, enxuto como Giacometti numa sala vazia e tão simplesmente eloquente como ele: depor palavras aos pés de uma escultura equivale às flores inúteis que se entregam aos mortos ou à dança da chuva em torno de um poço cheio: chiça para mim e para o romantismo meloso que me corre nas veias, minha eterna dificuldade em proferir palavras secas e exactas como pedras. Ergueu o queixo, bebeu um gole e deixou o líquido escorrer por ele (...), zangado 
consigo mesmo e com os torcidos de Crónica Feminina que se autogravara nos miolos, arquitecto da própria piroseira mau grado o aviso piloto de Van Gogh: tentei exprimir com o vermelho e o verde as terríveis paixões humanas. A brutal singeleza da frase do pintor arrepioulhe fisicamente as costelas como lhe acontecia, por exemplo, ao escutar o Requiem de Mozart ou o saxofone de Lester Young em These Foolish Things, correndo ao longo da música à maneira de dedos sábios por nádega adormecida (ANTUNES, 2009, p. 105; grifo meu).

Nesse percurso da escrita, encontra-se uma reunião de referências improvável, como o intérprete de fado Adriano Correia de Oliveira, para estabelecer contraste entre o gosto piegas arraigado (ou o sentimentalismo barato, uma possível definição para a expressão "rodriguinhos") e o seu texto "limpo, claro, directo, sem precisão de bonitezas" como um Giacometti que falaria por si só numa sala vazia. Esse procedimento metonímico de solicitação de referências como Giacometti para se referir à obra reincide no conjunto de narrativas aqui selecionadas. Pode-se inferir que o texto se realiza entre esse gosto herdado que coloca "franjas de crochet nos sentimentos" e toda uma tradição de arte redescoberta, re-escrita, pelo autor. Assim também como quando compara a frase atribuída a Van Gogh ao sentimento provocado pelo Requiem de Mozart e pelo saxofone de Lester Young em These foolish things. Esse procedimento comparativo será uma constante na fase inicial e se manterá nas crônicas.

Outra referência importante é a solicitação do pintor Goya para marcar a experiência da guerra, como aparece em Conhecimento do inferno: "O alferes encontrava-se nu da cintura para cima, em calções e sapatilhas, e as suas mamas amarelas e pendentes de gordo assemelhavam-no a uma dessas velhas de Goya que o pintor desenhava, no fim da vida, numa repugnância apaixonada e furiosa" (ANTUNES, 2010, p. 205; grifo meu). Seria preciso dizer tudo e maldizer o mundo para superar o trauma? Uma espécie de mal-estar se instala, porém um mal-estar tornado material fundante de escrita, num caminho poético para narrar a morte que a errância do texto consegue empreender:

Os vidros dos jipes cobriam-se de uma pele de lágrimas, as árvores embrulhavam-se de um celofane de vapor, brilhante e misterioso como o das pupilas dos doentes que nos fitam das almofadas com a humilde crueldade das crianças. O suicida acabara de morrer e jazia, tapado com um lençol, num cubículo vizinho, entre grades de cervejas vazias e caixotes de latas de conservas que prolongavam, se as cheirávamos, um estranho, denso, concentrado aroma de mar. Eram latas de sardinhas e de anchovas, latas de atum e de cavala, e o odor rodeava o morto como a água os corpos de pau dos afogados, que adquirem a pouco e pouco a 
consistência torturada e porosa das raízes. Sentíamos a presença dele com um olhar cravado nas costas, um olhar transparente, oco, repleto de indiferença e rancor, um olhar de ódio distraído e manso, o olhar de um inimigo que nos detesta e despreza e para o qual o candeeiro inclinava a única pétala da sua chama, numa inquietação de língua em busca do incisivo que lhe falta (ANTUNES, 2010, p. 204).

Em meio à narrativa dessas lembranças traumáticas, um cuidado meticuloso no emprego das palavras. Ao poético do texto loboantuniano atribui-se, além do ritmo e da disjunção nas quebras de linhas, o uso recorrente de metáfora ("sorrisos mortos"), metonímia (a mulher com "testa de Cranach"), sinédoque (os retratos a se dissolverem numa confusão de bigodes), e sobretudo de sinestesia, como no trecho acima: "uma pele de lágrimas", se referindo aos vidros embaçados, e o "aroma de mar" dos enlatados à maresia; ou mesmo o "riso gorduroso dos defuntos", para lembrar mais uma vez Os cus de Judas.

Para aquele que desejava a casa com paredes forradas de livros, como revela na carta $^{8}$ do dia 8 de maio de 1971, escrita a sua mulher Maria José em pleno combate, a guerra passará de ameaça a dispositivo, uma vez que o assunto tende a ser recorrente, como se observa também na própria fragmentação do texto e na quebra do fluxo narrativo. Não falar da guerra, o que não é o mesmo que ignorá-la, é deixar que o texto seja contaminado por outras experiências, quando narra, em suas crônicas, as anedotas de criança ou mesmo a lembrança de parentes e amigos já mortos, numa espécie de homenagem àqueles que compõem a sua memória e/ou o acompanham, assim, ao se referir à literatura, à música, ao cinema, à pintura, e, de modo especial, ao banal. A casa pode ser tomada aqui como o abrigo dessas lembranças que se tornarão escrita, onde o bibelô é apenas uma das chaves da rememoração. Pode-se inferir que a guerra é a rua, onde tudo aquilo que lhe fora ensinado no interior da casa é posto à prova. Assim o que lê, assim o que escreve. Basta saber se o mundo interior da casa descrito nos romances e crônicas, assim como as referências culturais, não é também uma forma de resistência de uma inocência perdida: o retrato de Parker colado na parede. As cartas de guerra apresentam o sonho de edificação de um projeto ambicioso misturado ao da casa: "O que eu quero é muitas prateleiras,

\footnotetext{
${ }^{8} \mathrm{O}$ conjunto das missivas compõe o livro D'este viver aqui neste papel descripto, organizado pelas filhas do casal e publicado em 2005, o que permitiu ao público o acesso às cartas de guerra escritas pelo ainda aspirante a escritor à sua esposa.
} 
sempre sonhei viver numa casa forrada de livros, ter pelo menos uma sala forrada de livros, e não ser preciso tirar 500 de cima para ler um de baixo" (ANTUNES, 2005, p. 153).

Sobre o aprendizado buscado nos livros, se referindo a Hemingway, sem ter se dado conta na adolescência do quanto podia aprender com esse escritor norte-americano, Lobo Antunes fala das soluções técnicas aparentemente fáceis e que só muito tarde veio a aprender que "a primeira versão tem dentro dela as soluções do texto", ocorrendo-lhe ir à rua, "ao contentor de lixo, buscar coisas que tinha escrito antes" (In: ARNAUT, 2008, p. 258). Quando perguntado sobre influências, o autor de Explicação dos pássaros fala daquelas buscadas no cinema norte-americano e italiano, assim como nos andamentos da música. Da literatura, cita Júlio Verne e Emílio Salgari, atribuindo a eles o começo, porém, à medida que se busca um jeito próprio, a procura "desesperada e impaciente de uma maneira especial de dizer as coisas", segundo Lobo Antunes, "é preciso negar todos os outros escritores, evitar o 'está-me a soar a', ou o que é ainda mais grave, o 'isto está-me a soar a mim próprio', que é quando a gente começa a se repetir” (In: ARNAUT, 2008, p. 258). Talvez porque, conforme Blanchot:

A poesia não é dada ao poeta como uma verdade e uma certeza de que ele poderia aproximar-se; ele não sabe se é poeta, mas tampouco sabe o que é poesia, nem mesmo se ela é; ela depende dele, de sua busca, dependência que, entretanto, não o torna senhor do que busca mas torna-o incerto de si mesmo e como que inexistente (1987, p. 83).

No terceiro livro da sua aprendizagem, o já referido Conhecimento do inferno, Lobo Antunes começa por falar do mar do Algarve que, segundo o narrador, "é feito de cartão como nos cenários de teatro" que os ingleses não percebem. Aqui, faz uma decupagem desse lugar, cuja imagem parece tão gasta pelo turismo e pela publicidade que se vende nas ruas, que, de tanto ser vista, já não se consegue ver. O narrador, que anuncia uma viagem solitária de carro do Algarve a Lisboa, cria uma linguagem metafórica que remete ao cenário tipicamente teatral e cinematográfico: "esplanadas postiças", "bebidas inventadas em copos que não existem, as quais deixam na boca o sabor sem gosto dos uísques fornecidos aos figurantes durante os dramas da televisão", "aurora de celofane", "mar de cartolina", "arbustos de plástico", "relva envernizada" - em meio a comparações que fazem surgir no texto "a menina do anúncio dos colchões Repimpa”, "os óculos de Greta Garbo", o "sabonete Ach Brito". Para então falar das "nuvens redondas" que balançavam “docemente penduradas por fio de nylon dos grampos transparentes do ar". Como se nos 
bastidores desse cenário teatral, ao levantar a cortina, a memória recuperasse cenas da guerra e o texto se lançasse para a paisagem de Angola. Característica já esboçada em Memória de elefante e potencializada em Os cus de Judas quando o autor promove uma fusão de diversos tempos. O tempo da narrativa, o tempo da infância e da juventude, o tempo da guerra, atravessados por rastros de personalidades e imagens, sejam buscadas nos livros, filmes, músicas, cartazes de publicidade, personalidades que podem ser convocadas principalmente pela possibilidade imagética do cinema que se presentifica numa ação e se dissolve no choque com a "realidade", conforme relata:

(...) ainda hoje, sabe, saio do cinema a acender o cigarro à maneira de Humphrey Bogart, até que a visão da minha imagem num vidro me desiluda: em vez de caminhar para os braços de Lauren Bacall dirijo-me de facto para a Picheleira, e a ilusão desaba no fragor lancinante de um mito desfeito (ANTUNES, 2003, p. 39; grifo meu).

Percebe-se, em Lobo Antunes, um constante desdobrar-se, uma liberdade em citar que se mistura ao menor, permitindo vislumbrar a hipótese que aqui se defende. O "banal" é um aproveitamento de tudo que pode coletar também da indústria cultural cinematográfica, cujo gesto mais corriqueiro de acender um cigarro, uma vez ampliado numa tela de projeção, retorna na escrita "à maneira de".

Como um escritor que trabalha quase que ininterruptamente, tendo em vista não apenas o tempo dedicado aos romances, mas também, nas horas que lhe restam, à dedicação a suas crônicas, poder-se-ia afirmar que em Lobo Antunes, como para muitos escritores de sua escolha, não existe separação entre vida e escrita. Se para Kafka, segundo Ricardo Piglia, "a escrita existe caso tenham sido criadas as condições que a possibilitam" (2006, p. 48), se referindo à continuidade do ato de escrever, sem resistência, que a vida deve se submeter, Lobo Antunes dispõe de horas e horas debruçado sobre a tarefa:

O meu ritmo é infernal, trabalho doze horas por dia. Quando viajo para apresentar um livro e tenho de fazer entrevistas e tudo o que implica a sua promoção, recupero o tempo perdido durante a noite e escrevo até às duas ou às quatro da madrugada. É-me indiferente estar na Alemanha, na Áustria ou em Espanha ou que me levante muito cedo ou estar cansado, eu tenho de escrever todos os dias, preciso disso para não me sentir culpado (In: BLANCO, 2002, p. 26).

Escrevendo no espaço mínimo de receituários do Hospital Miguel Bombarda, o mesmo papel onde se prescreve no decurso de uma doença, em letra mínima, o texto, que será depois entregue ao editor e transcrito por assistentes à máquina, se desenvolve num 
emaranhado de notas e marcações quase que ilegíveis num primeiro contato com o manuscrito, como pode ser visto nos fac-símiles disponíveis em Conversas com António Lobo Antunes e na sua Fotobiografia. Ao passo que fala da escrita, Lobo Antunes sempre se remete às suas leituras, o homem que lê não se distingue assim do homem que escreve, o mesmo que observa os objetos à sua volta, como pode ser constatado no trecho abaixo em que discorre sobre a velhice:

(...) mudei e não compreendo muito bem os capítulos anteriores da minha vida. Continuo a ver-me como há vinte anos; por vezes penso no final da Recherche de Proust, quando ele tem a sensação de que está num baile de máscaras, que as suas rugas estão pintadas e o seu cabelo tingido de branco. Ainda tenho um olhar virgem para muitíssimas coisas, a sensação de que ainda tenho muito para viver, no entanto, o espelho e os outros coagulam-me numa imagem de velho (In: BLANCO, 2002, p. 122).

Lobo Antunes faz uma reflexão sobre o tempo ser insuficiente para: os livros ainda não lidos, lugares e pessoas por conhecer, encontros preciosos que nunca terá. Ao mesmo tempo identifica que toda a gente é sempre a mesma, "elimina-se o pequeno verniz da diferença e somos todos o mesmo, se não não nos emocionaríamos todos com Tchekhov" (In: BLANCO, 2002, p. 122), estando ele entre os homens, e não acima deles, sendo "apenas mais um", afirmativa que atribui a um escritor espanhol, Gabriel Celaya. A sua fala, bem como sua escrita, recorre a tais referências para mediar ou significar sentimentos, passagens da sua vida, seu pensamento sobre o fazer literário, seu procedimento de escrita. Nesse sentido, pode-se afirmar que Proust não é apenas um escritor de leitura fundamental na sua formação, mas um significante importante para se pensar a memória, um intercessor tanto nessa mediação da fala, quanto da escrita.

Em Lobo Antunes, há um desejo latente de se fixar ao mundo em diminuto que coexiste com o mundo de referências já instituídas; persiste um desejo genuíno de se agarrar aos detalhes, dar franjas aos sentimentos, por menor e menos seguro seja; encontrar uma afirmação também nesse lugar da escrita, consciente de que "verdade" e "certeza" são transitórias, frágeis como vidro. Enquanto a dúvida o acompanhar, a tarefa não será suspensa, permanecendo, obviamente, o risco de se repetir. Mas enquanto o livro o solicitar, sua ameaça de abandonar a escrita vai sendo adiada. E o que dizer dos chamados aflitos das vozes no posto de socorro? "Escute, preciso tanto que me escute", seria o apelo do narrador de Os cus de Judas para a mulher-ouvinte ou do jovem soldado à esposa? Os 


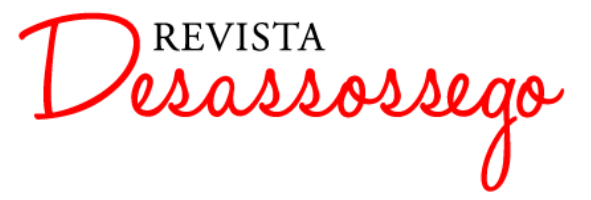

nativos pedindo remédios ou os internos do Hospital Miguel Bombarda um consolo? Sabese de vozes silenciadas e daquelas a se silenciar. De outro modo, o autor fala respeitosamente daquele que o lê, como pode ser constatado na "Crónica ao espelho", do Quarto livro de crônicas. Sentado a uma pequena mesa, num quarto de hotel, em frente a um espelho, se pondo a escrever como de hábito, num lugar que lhe parece sempre o mesmo, diz: "as pessoas que me lêem comovem-me: fiz um livro diferente para cada uma delas, com palavras diferentes, do mesmo jeito que um alfaiate trabalha por medida, porque a vida de cada um é única, nunca existiu ninguém antes", e prossegue: "as experiências podem ser parecidas, a maneira de vivê-las diversa: somos mundos sem fim" (ANTUNES, 2011, p. 245-246).

Dada a incerteza relativamente ao êxito da tarefa, se há alguma garantia, ela só pode se dar na continuidade da escrita, pondo mãos à obra, para lembrar Blanchot. Vale ressaltar ainda, uma das treze teses de Walter Benjamin sobre a técnica do escritor: "jamais deixe de escrever porque nada mais lhe ocorre. É um mandamento de honra literária só interromper quando um prazo (...) deve ser observado ou a obra está terminada". Além de outra: "nunca considere como perfeita uma obra sobre a qual não se sentou uma vez desde a noite até o dia claro" (BENJAMIN, 2013, p. 28). Poder-se-ia dizer que enquanto a maioria das pessoas dorme o sono dos justos, o escritor está lá, em vigília, à procura talvez da “outra noite" blanchotiana, até que a obra possa vir à claridade, não bem romances, mas "visões, morar nelas como num sonho cuja textura é a nossa própria carne, cujos olhos, tal os olhos dos cegos, entendem o movimento, os cheiros, os ruídos, a subterrânea essência do silêncio" (ANTUNES, 2006, p. 134), confessa o trapeiro:

Sou muito claro a respeito do que julgo ser a arte de escrever um romance: não existe um sentido exclusivo e este não tende

(tal como nós)

para uma conclusão definitiva. A única forma de o ler consiste em trocar a obsessão da análise por uma compreensão dupla, se assim me posso exprimir: acharmo-nos, ao mesmo tempo, no interior e por fora da intensidade inicial, ou seja do conflito entre o quotidiano e o esmagamento cósmico, atemorizados pelo horror e a alegria primitivas, vagando sem cálculo nem sentido, pelo ermo dos dias.

Interessante pensar numa instância autobiográfica na qual a imagem do trapeiro retorna, aquele para quem o poeta moderno projeta o olhar, considerando o gesto de recolher tudo que é deitado fora, detritos e fragmentos de objetos, citações e tempo, como 
matéria de escrita. Mesmo sem se referir diretamente a ele, Baudelaire ressurge e se faz presente como imagem literária. Ao analisar a escrita autobiográfica na obra de Lobo Antunes, Maria Alzira Seixo diz que:

se por um lado [os romances] se apresentam como ficções, por outro lado (e a partir de depoimentos do autor em entrevistas, crónicas ou de outros ditos que, não vá sem ser dito, não têm o mesmo selo de garantia dos textos publicados como romances) não enjeitam esse lado vivido, a consagração de uma experiência e de uma carreira extraliterária que tem sido a do escritor e é documentada pela sua existência civil (2002, p. 474).

Seixo trabalha com a perspectiva inventiva e sedutora do escritor que se apropria de dados vividos e às vezes do próprio nome para a construção de suas narrativas. Para a estudiosa e talvez maior incentivadora crítica dessa obra, pode-se encarar a questão autobiográfica de ângulos muito diversos, quando tomada como gênero, "escrita do eu que compõe suas remissões referenciais", como composição memorialística, a relação do relato com "eventual discurso da História”, todavia, seja como for, afirma:

o problema que a autobiografia (...) coloca é o de que, em literatura, a subjectividade da escrita acarreta, de forma mais ou menos evidenciada ou mais ou menos subtil, a projeção de uma circunstância efectiva directa, transformada, reelaborada ou contrastiva, que de algum modo aponta para o autor que escreve (2002, p. 475).

O aproveitamento do vivido, sem dúvida, não se dá apenas pelo reflexo das imagens do horror, seja da guerra, seja do hospital psiquiátrico, em sua obra, mas também por tudo aquilo que se faz presente na vida literária, a memória individual atravessada pela memória cultural. No segundo volume de Os romances de António Lobo Antunes, Seixo retomará os romances e crônicas propondo uma reflexão sobre a composição poética que se realiza nesse universo, tanto de caráter ficcional, quanto de teor autobiográfico, trabalhando eixos de significações constantes na obra, como a presença de "uma atmosfera radicada na paisagem, urbana e natural, na qual se destacam seres inanimados" (2010, p. 17), e a presença das flores desde sua implicação no enredo ou nos sentimentos manifestados na enunciação, até sua relação com o kitsch," "nas representações

\footnotetext{
${ }^{9}$ Denis Leandro Francisco faz várias referências ao kitsch na obra de Lobo Antunes, destaco a passagem que se refere às duas casas habitadas pela personagem de Que farei quando tudo arde?, segundo o pesquisador: "o espaço do passado é reatualizado pela memória desse sujeito habitante que está em uma e em outra casa - ou entre uma e outra, já que não pode decidir-se por nenhuma. Essa casa ficcional - repleta de cômodos e móveis atulhados de pequenos bibelôs, de enfeites de porcelana, de forros e cortinas de naperon - esboça um quadro do kitsch como uma das tendências da 'cosmicidade' ficcional antuniana, essa 'cosmicidade' que (...)
} 
referenciadas do plástico ou do pano, relacionadas com cenários de falsidade ou de sensibilidade postiça, ou ainda iletrada, e com gosto duvidoso" (SEIXO, 2010, p. 17).

Embora Lobo Antunes se refira publicamente às crônicas como algo secundário, Seixo chama a atenção à retórica do autor, que constrói em suas entrevistas uma imagem que se entenda por conveniente. Lobo Antunes parece criar nesses espaços de escrita um incidente biográfico. Para o próprio autor todos os seus romances seriam a sua biografia, uma vez que tudo passa por ele. Uma biografia de caráter polifônico, tendo as vozes de seus romances e crônicas muito ou pouco a dizer de seu autor que, por deixar escapar um traço que o encontra, logo se perde em outro, num emaranhado de dizeres, mediados por outras tantas vozes selecionadas e atualizadas. Esse discurso se amplia numa multiplicidade de saberes, muitas vezes conflitantes, outras consonantes, e, para Lobo Antunes, cabe a difícil tarefa de por o mundo dentro das páginas de um livro. O que parece importar é a escrita como atividade onde tudo se torna matéria, onde tudo é reaproveitado, reciclado; atualizado, portanto.

Nesse ato de rememorar, evocar a tradição de escrita, as outras artes e o banal, a imagem de Proust se torna um importante significante para a memória, conforme já dito, tendo em vista a relação que o escritor estabelece com o presente (a escrita) e o passado, para onde se projeta o olhar - uma relação que inevitavelmente atualiza o passado (lembrando a análise borgiana sobre os precursores de Kafka), problematizando-o, uma vez que o olhar não detém a verdade sobre os acontecimentos, talvez por isso seja preciso se lançar numa busca constante. Proust, ou o seu espectro, para utilizar uma metáfora de Lobo Antunes, é uma referência importante para se pensar o escrever, por tudo que representa a busca em relação à memória e à escrita. O poder de movimentar, como uma máquina, lembranças, mediadas por referências canônicas e da cultura industrial. Ao dar “franjas aos sentimentos”, Lobo Antunes parece sempre encontrar o menino que se agarra a pequenos achados, cujas aventuras estavam circunscritas ao quintal, e a perda desse mundo e seus vestígios se aninham na escrita, a elaboração própria dessa perda.

\section{Referências}

manifesta-se nas cadeiras de plástico descartáveis, nos bibelôs quebrados e insistentemente colados, nos móveis e eletrodomésticos estragados e repetidamente reparados” (2011, p. 114). 
ANTUNES, António Lobo. Quarto livro de crónicas. Lisboa: Dom Quixote, 2011. . Conbecimento do inferno. 15 ed. Lisboa: Publicações D. Quixote, 2010.

_. D'este viver aqui neste papel descripto - Cartas de Guerra. Maria José e Joana Lobo Antunes (Orgs.). Lisboa: Publicações Dom Quixote, 2005.

. Memória de elefante. 27 ed. Lisboa: Publicações D. Quixote, 2009.

. Terceiro livro de crónicas. Lisboa: Dom Quixote, 2006.

. Os cus de Judas. Rio de Janeiro: Objetiva, 2003.

ARNAUT, Ana Paula (Org.). António Lobo Antunes: Confissões do Trapeiro (1979-2007). Coimbra: Almedina, 2008.

BENJAMIN, Walter. Rua de mão única. Trad. João Barrento. Belo Horizonte: Autêntica, 2013.

BLANCHOT, Maurice. O espaço literário. Rio de Janeiro: Rocco, 1987.

BLANCO, Maria Luisa. Conversas com António Lobo Antunes. 2. ed. Lisboa: Dom Quixote, 2002.

COELHO, Tereza. Fotobiografia de António Lobo Antunes. $2^{\mathrm{a}}$ ed. Lisboa: Dom Quixote, 2004.

FRANCISCO, Denis Leandro. Textualidades em negativo: a ficção de António Lobo Antunes. 2011. 286f. Tese (Doutorado em Letras) - Universidade Federal de Minas Gerais.

HESS, Jacques B. O jazz. In: MASSIN, Jean; MASSIN, Brigitte (Org.). História da música ocidental. Rio de Janeiro: Nova Fronteira, 1997. p. 1063-1121.

PIGLIA, Ricardo. Memoria e tradición. In: Anais do $2^{\circ}$ Congresso da Abralic (1991), v. 1, p. 60-66.

. O último leitor. São Paulo: Companhia das Letras, 2006.

SEIXO, Maria Alzira. As flores do inferno. Lisboa: Dom Quixote, 2010.

. Os romances de António Lobo Antunes. Lisboa: Dom Quixote, 2002. 